\title{
Membentuk Sumber Daya Manusia Perbankan Syariah Melalui Manajemen Hati
}

\author{
Mahmudah Mulia Muhammad \\ Universitas Islam Negeri Alauddin Makassar \\ Email: Udha009@gmail.com
}

\begin{abstract}
This paper aims to determine the formation of human resources in Islamic banking through careful management. The results of the analysis show that the management of the heart of the formation of human resources is an effort to manage the hearts of all employees who aim to shape the characteristics of human resources that are cultured and divine. Heart management that can be carried out by Islamic banking through the formation of spiritual intelligence (Aliman al-'amiq, Al-ittishal al-watsiq and Tathhir al-qalb), and emotional formation (Self Awareness, Motivation, Empathy and Social Skills).
\end{abstract}

Keywords: Heart Management, Human Resources, Islamic Banking.

\begin{abstract}
Abstrak
Tulisan ini bertujuan untuk mengetahui pembentukan sumber daya manusia perbankan syariah melalui manajemen hati. Hasil analisis menunjukkan bahwa manajemen hati dari pembentukan sumber daya manusia merupakan suatu upaya pengelolaan hati untuk seluruh karyawan yang bertujuan untuk membentuk karaktek sumber daya manusia yang berbudaya dan bernilai ketuhanan. Manajemen hati yang dapat dilakukan oleh perbankan syariah melalui pembentukan kecerdasan spiritual (Al-iman al-`amiq, Al-ittishal al-watsiq dan Tathhir al-qalb), dan pembenukan emosional (Self Awareness, Motivation, Empathy dan Social Skills).
\end{abstract}

Kata Kunci : Manajemen Hati, Perbankan Syariah, Sumber Daya Manusia.

\section{PENDAHULUAN}

Perkembangan perbankan syariah telah mengalami pertumbuhan yang sangat pesat, baik dari sisi pertumbuhan aset maupun pertumbuhan kelembagaan atau jaringan. ${ }^{1}$ Disahkannya Undang-Undang Nomor 21 Tahun 2008 tentang Perbankan Syariah, selanjutnya disingkat UUPS 2008, disambut gembira para

\footnotetext{
${ }^{1}$ Hairiennisa Rohaya, "Perkembangan Skala Usaha Perbankan Syariah di Indonesia Pra dan Pasca Kebijakan Office Channeling”, La-Riba, Vol. II, No. 2, (Desember 2008), h. 191. 
pelaku industri perbankan syariah di tanah air dan sebagian masyarakat muslim khususnya. ${ }^{2}$

Bank Muamalat Indonesia sebagai bank syariah pertama dan menjadi pioneer bagi bank syariah lainnya, dan telah lebih dahulu menerapkan sistem ini di tengah menjamurnya bank-bank konvensional. Krisis moneter yang terjadi pada tahun 1998 telah menenggelamkan bank-bank konvensional dan banyak yang dilikuidasi karena kegagalan sistem bunganya. Sementara perbankan yang menerapkan sistem syariah dapat tetap eksis dan mampu bertahan. ${ }^{3}$

Perkembangan bank syariah yang pesat dari segi kuantitas tidak diikuti dengan perkembangan kualias sumber daya manusia. Permasalahan seperti ini menjadi perhatian yang serius dari berbagi kalangan. Pembentukan sumber daya manusia yang handal dan cerdas dari segi ESQ masih menjadi problemaika dalam dunia perbankan syariah.

Kecerdasan yang dipahami masyarakat pada umumnya berkaitan dengan kecerdasan intelegensi atau kecerdasan intelektual (Intelegency Quotient).Sesuai dengan perkembangan pengetahuan manusia, maka ditemukan tipe kecerdasan lainnya melalui penelitian-penelitian empiris oleh para akademisi dan praktisi psikologi, yakni kecerdasan emosional (emotional quotient) dan kecerdasan spiritual spiritual quotient). ${ }^{4}$

Dalam kerangka kecerdasan spiritual, perilaku orang dalam bekerja, berbisnis atau berorganisasi adalah aktualisasi diri yang bersumber pada internal motivation, yaitu kesadaran dan tanggungjawab dalam bekerja timbul dari keyakinan bahwa prestasi adalah bagian dari ibadah yang berkualitas. Konsep spiritual management dalam bahasa K.H. Abdullah Gymnastiar diperkenalkan

${ }^{2}$ Dede Nurohman, "Undang-Undang Perbankan Syariah: Makna, Implikasi dan Tantangan", La-Riba, Vol. II, No. 2, (Desember 2008), h. 279.

${ }^{3}$ Nofinawati, "Perkembangan Perbankan Syariah di Indonesia",Juris, Volume 14, Nomor 2 (Juli-Desember 2015), h. 67.

${ }^{4}$ Armansyah, "Intelegency Quotient, Emotional Quotient, and Spiritual Quotient dalam Membentuk Perilaku Kerja”, Jurnal Ilmiah Manajemen \& Bisnis, Vol. 02 No. 01, (2002), h. 2332 . 
dengan istilah Manajemen Qalbu yang bertumpu pada religious mind-set yang meletakkan hubungan antar manusia dalam proses bisnis atau kerja, tidak lepas kaitannya dengan hubungan manusia dengan Tuhannya. Outcome yang diharapkan dari implementasi konsep ini adalah bahwa manusia siapapun yang terlibat dalam proses bisnis, harus memiliki kesadaran, apapun yang mereka perbuat harus berlandaskan pada keimanan dan ketakwaannya kepada Tuhan. ${ }^{5}$

Bertumpu pada hal tersebut di atas, maka dalam berbagai rekrutmen maupun manajemen sumber daya manusia dalam industri perbankan syariah seharusnya dilakukan melalui pendekatan manajemen hati dengan harapan sumber daya manusia yang dihasilkan mampu menghadapi tantangan yang besar sehingga perbankan syariah mampu bersaing dengan perbankan konvensional baik dari segi kuantitas maupun kualitas.

\section{PEMBAHASAN}

\section{A. Problem Sumber Daya Manusia Perbankan Syariah}

Praktisi perbankan syariah sekarang ini masih didominasi oleh kelompok pindahan konvensional, sehingga, secara logis jiwa yang ada dalam sanubari praktisi perbankan syariah kini mayoritas masih dalam tahap bagaimana ia bisa menerapkan, belum mencapai taraf bagaimana ia bisa mengembangkan,sehingga program sosialisasi yang sering digembar-gemborkan terlihat semu karena dan ketidakseimbangan antar data yang disosialisasikan dengan fakta yang berkembang.

Diperlukan sinergi yang secara solid, sistematis, dan terencana dari seluruh praktisi secara struktural untuk mengubah kualitas karyawan yang sebelumnya konvensional menjadi syariah sistem perbankan syariah ini. Tentu hal ini harus diikuti dukungan dari pemerintah (Depkeu, BI, departemen terkait), ulama, parlemen (DPR/DPRD), perguruan tinggi, pengusaha (hartawan Muslim), ormas Islam dan masyarakat Islam pada umumnya membumikan ekonomi syariah.

\footnotetext{
${ }^{5}$ Muflihatul Bariroh, "Implementasi Manajemen Hati Sebagai Upaya Peningkatan Sumber Daya Manusia di Mayangkara Group", An-Nisbah: Jurnal Ekonomi Syariah, Volume 05, Nomor 02, (April 2019), h. 3.
}

31 
Keseimbangan antara sosialisasi dan edukasi masyarakat dari seluruh kalangan yang terkait seperti yang telah disebutkan diatas. Selain itu juga perlu diadakannya reformasi regulasi sistem perekonomian di Indonesia yang bersifat destruktif dan sesuai dengan tujuan maslahah bagi seluruh rakyat indonesia. Karena secara tidak langsung konsep perekonomian kapitalis dan kolonial yang masih belum lepas mekanisme perekonomian bangsa, ikut mempengaruhi pola pikir masyarakat sebagai subjek dan objek dari sistem perekonomian secara umum dan perbankan secara khusus.

Perbankan syariah di Indonesia perlu memiliki sumber daya manusia (SDM) andal yang mampu memahami prinsip-prinsip kesyariahan. Selama ini masih banyak SDM perbankan syariah berasal dari bank konvensional sehingga kondisi itu menyebabkan penerapan sistem bagi hasil (murabahah) agak ditinggalkan,semua perbankan syariah di Indonesia hingga sekarang memang belum banyak yang menerapkan prinsip syariah. Hal itu perlu menjadi pemicu perbankan syariah untuk memiliki SDM andal yang memahami prinsip syariah. Manajemen SDM perbankan syariah sudah saatnya ditingkatkan untuk mewujudkan sistem perbankan syariah yang benar.

\section{B. Manajemen Hati dan Kaitannya dengan ESQ}

Hati merupakan terjemah dari kata qalbu yang digunakan untuk menyebut hati baik dalam arti fisik maupun secara maknawi. Qalbu dikenal dengan hati nurani atau lubuk hati yang merupakan sarana terpenting yang telah dikaruniakan oleh Allah kepada manusia serta tempat bersemayamnya suatu niat yakni sesuatu yang menentukan nilai perbuatan seseorang. Hati yang dalam bahasa Arab disebut qalbun dan dalam bahasa kita disebut kalbu, mengandung makna berbolak-balik atau berubah-ubah.

Manajemen hati dapat diartikan suatu upaya pengelolaan hati supaya potensi positifnya bisa berkembang maksimal mengiringi kemampuan berpikir dan bertindak sehingga sekujur sikapnya menjadi positif. Manajemen hati berupaya mengatur hati dengan jalan berlatih secara terus menerus bagaimana hati menyikapi segala persoalan yang dihadapi dalam kehidupan sehari-hari. Melalui manajemen qalbu, hati manusia akan dikelola sehinggadapat menjadi hari yang bersih.

Kaitan manajemen hati dengan ESQ, pada mulanya kecerdasan hanya berkaitan dengan kemampuan struktur akal yang hanya bersentuhan dengan aspek-aspek kecerdasan kognitif saja. Namun pada perkembangannya, ditemukan suatu teori bahwa kecerdasan bukan hanya mengenai struktur akal, melainkan terdapat struktur hati yang

\section{2}


perlu mendapat tempat tersendiri untuk menumbuhkan aspek-aspek afektif, seperti kehidupan moral, emosional, dan spiritual.

Pentingnya hati untuk dibina demi baiknya kondisi seseorang terutama kecerdasan spiritualnya. Jika hati dibina dengan baik maka kondisi kecerdasan spiritual akan baik, sehingga akan berimplikasi terhadap meningkatnya kualitas diri seseorang dan lahir manusia-manusia yang baik serta paripurna dan terciptanya sumber daya manusia yang berkualitas.

\section{Pembentukan SDM Perbankan Syariah Melalui Manajemen Hati}

Manusia diciptakan oleh sang pencipta dengan berbekal kekuatan yang luar biasa. Namun kekuatanitu tersembunyi dibalik diri manusia itu sendiri. Jika kita bisa mengotimalkan kekuatan yang luarbiasa tersebut maka bukan tidak mungkin kita akan menjadi manusia yang luar biasa. Kekuatanyang perlu dikembangkan oleh manusia diantaranya meliputi kekuatan spriritual dan kekuatan emosional.

Manusia diciptakan oleh Allah sebagai mahluk paling tinggi dibanding dengan mahluk ciptaanAllah yang lain. Manusia dibekali dengan akal dan hawa hawa nafsu. Jika dimanfaatkan secaramaksimal maka kemampuan manusia menjadi luar biasa. Membentuk kekuatan spriritual dapat dilakukan melalui tiga cara yaitu:

1. Al-iman al-`amiq, yaitu memperkuat iman kepada Allah swt dengan selalumengesakan dan menyandarkan diri hanya kepada-Nya. Perbankan syariah dalam membentuk SDM melalui al-iman al-`amiq dapat dilakukan dengan pemberian program Baca Tulis al-Quran (BTQ) kepada para karyawan perbankan syariah tanpa terkecuali. Pelaksanaan program BTQ menjadi cerminan keteguhan keyakinan para karyawan dalam memeluk agama Islam. Praktik agama yang dijalankan akan sangat memengaruhi tingkah laku karyawan dalam bekerja dan kontrol diri agar tidak mudah melakukan perbuatan yang merugikan orang lain.

2. Al-ittishal al-watsiq, yaitu membangun hubungan dan komunikasi yang kuat denganAllah swt. Komunikasi dilakukan dengan ibadah dan senantiasa mendekatkan diri kepada-Nyamelalui ibadah-ibadah wajib (al-mafrudhat) ataupun ibadah-ibadah sunah (al-mandubat). Perbankan syariah dalam membentuk SDM melaluial-ittishal al-watsiq dapat dilakukan melalui pemberlakuan shalat berjamaah di kantor perbankan syariah, bukan hanya untuk 
karyawan tetapi dilakukan bersama pimpinan dengan harapan akan terbentuk sebuah sinergi dalam lingkungan organisasi.

3. Tathhir al-qalb, yaitu upaya menyucikan diri dari berbagai penyakit hati. Perbankan syariah dalam membentuk SDM melaluitathhir al-qalb dapat dilakukan melalui penyelenggaraan program tausiah. Isi tausiyah berisi muhasabah diri, ajakan untuk senantiasa berdzikir kepada Allah dimanapun dan kapanpun berada dan motivasi agar para karyawan selalu semangat dalam bekerja serta selalu mengingatkan bahwa tujuan utama dalam bekerja adalah ibadah.

Setiap manusia pasti mempunyai kepribadian, keinginan dan kebutuhan yang berbeda-beda.Perbedaan tersebut menunjukan bagaimana emosi kita. Jika kita cermat mengenali perbedaan ini,maka sukses akan datang dalam hidup kita. Itulah mengapa pentingnya kecerdasan emosional. Membentuk kekuatan emosional dapat dilakukan melalui lima cara yaitu:

1. Self Awarenes atau kesadaran diri sendiri adalah salah satu karakter kecerdasan emosional. Orang dengan kecerdasan emosional tidak akan membuat perasaan merekamenjadi dominan dalam sebuah situasi. Emosi mereka tidak boleh mengendalikanperilakunya sehingga dapat merusak kontrol terhadap lingkungan. Kesadaran diri yang baik membuat seorangkaryawan dapat tampil dengan keyakinan diri,sehingga dapat berbuat tegas dan mampumembuat keputusan yang baik dalam keadaantidak pasti dan tertekan.

2. Self Regulation adalah kemampuan dalam mengendalikan emosi dengan adanya stimulan dari luar. Merekatidak akan membiarkan situasi dan kondisi menjadikannya marah atau kecewa yangberlebihan, menjadi implusif dan bertindak ceroboh. Seorang karyawan yang mampu mengaturemosi diri yang baik akan memiliki rasatanggung jawab atas kinerjanya pribadi danmempunyai kemampuan beradaptasi dalammenghadapi berbagai perubahan. Mengaturemosi membuat seorang karyawan dapatmengendalikan pikiran untuk tetap tenangmengerjakan tugas pribadinya.

3. Motivation yaitu orang dengan kecerdasan emosional akan selalu termotivasi, bersedia menjalani prosesuntuk sukses jangka panjang, menunjukkan produktivitas tinggi, mencintai tantangan danefektif dalam pekerjaannya. 
Kemampuan untuk memotivasi diri sendiri akanmembuat karyawan menjadi lebih semangatdalam bekerja, sehingga kinerjanya akan meningkat.

4. Empathy merupakan salah satu yang terpenting dalam kecerdasan emosional, yakniempati kepada orang lain. Dapat merasakan apa yang dialami orang lain dan mampumelihat dari sudut pandang mereka. Orang yang empatik akan mudah membina hubunganpersonal, dan seorang pendengar yang baik. Kemampuan berempati membuat seseorangmenjadi mudah untuk diterima banyak orangdan merasa dihargai, begitu pula hal yang samadirasakan oleh orang lain yang merasa dirinyadihargai dengan pemikiran yang mempunyaiperbedaan sudut pandang.

5. Social Skillsyaitu kemampuan bekerja sama dalam tim dan fokus menolong dan membantu orang lain terlebihdahulu dibandingkan sukses pribadi. Orang dengan social skills adalah pribadi yang enakdiajak bicara, pribadi yang handal dalam berkomunikasi dan membangun hubungan personal. Ketrampilan sosial yaitu kemampuan untukmenangani emosi dengan baik dan berinteraksidengan lancarketika berhubungan dengan oranglain, mempengaruhi dan memimpin orang lain,dapat menyelesaikan perselisihan dan untukbekerja sama dalam tim.

\section{PENUTUP}

\section{A.Kesimpulan}

Berdasarkan pembahasan diatas maka, disimpulkan sebagai berikut:

1) Kualitas SDM perbankan syariah sekarang ini masih didominasi oleh konvensional sehingga diperlukan sinergi yang secara solid, sistematis, dan terencana dari seluruh praktisi secara struktural untuk mengubah kualitas karyawan yang sebelumnya konvensional menjadi syariah sistem perbankan syariah ini. Konsidi seperti ini dapat diubah melalui manajemen hati. Manajemen hati berupaya mengatur hati dengan jalan berlatih secara terus menerus bagaimana hati menyikapi segala persoalan yang dihadapi dalam kehidupan sehari-hari.

2) Implikasi manajemen hati yang mampu membentuk pribadi dan karakter karyawan perbankan syariah dilakukan melalui pembentukan kecerdasan spiritual dan kecerdasan emosional karyawan perbankan syariah.

\section{5}




\section{DAFTAR PUSTAKA}

Abdusshomad, Muhyiddin. Etika Bergaul; di Tengah gelombang Perubahan:Kajian Kitab Kuning. Surabaya: Khalista, 2007.

Arifin, Zainul. Memahami Bank Syariah: Lingkup, Peluang, Tantangan dan Prospek. Jakarta: AlvaBet, 2000.

Armansyah. "Intelegency Quotient, Emotional Quotient, and Spiritual Quotient dalam Membentuk Perilaku Kerja".Jurnal Ilmiah Manajemen \& Bisnis. Vol. 02 No. 01, (2002).

Bariroh, Muflihatul. "Implementasi Manajemen Hati Sebagai Upaya Peningkatan Sumber Daya Manusia di Mayangkara Group".An-Nisbah: Jurnal Ekonomi Syariah. Volume 05, Nomor 02, (April 2019).

Haryanto, Rudy. "Bagi Hasil dan Bank Syariah (Solusi terhadap Bunga Bank)".Al-Ahkam. Vol.V No.2 (Desember 2010).

Muhammad. Lembaga Keuangan Kontemporer. Yogyakarta: UII Press, 2000.

Mujib, Abdul dan Yusuf Mudzakir.Nuansa-nuansa Psikologi Islami. Jakarta: PT. Raja Grafindo Persada, 2002.

Nawawi, Hadari. Manajemen Sumber Daya Manusia: untuk Bisnis yangKompetitif. Yogyakarta: Gadjah Mada University Press, 2011.

Nofinawati."Perkembangan Perbankan Syariah di Indonesia".Juris. Volume 14, Nomor 2 (Juli-Desember 2015).

Nurohman, Dede. "Undang-Undang Perbankan Syariah: Makna, Implikasi dan Tantangan".La-Riba. Vol. II, No. 2, (Desember 2008).

Rohaya, Hairiennisa. "Perkembangan Skala Usaha Perbankan Syariah di Indonesia Pra dan Pasca Kebijakan Office Channeling". La-Riba. Vol. II, No. 2, (Desember 2008).

Satiadarma, Monty P. dan Fidelis E. Waruwu.Mendidik Kecerdasan. Jakart: Pustaka Populer, 2003.

Yusuf, Burhanuddin. Manajemen Sumber Daya Manusia. Jakarta: Rajawali Pers, 2015. 